\title{
KOGNITIF DEVELOPMENT: Mencermati Siklus Pertumbuhan Kognitif Anak
}

\author{
Oleh: \\ Khulusinniyah \\ Fakultas Tarbiyah IAI Ibrahimy Situbondo \\ niakhulusi84@gmail.com luci
}

\begin{abstract}
Cognitive development should be considered early, because without the appropriate stimulation these aspects can't develop optimally. Cognitive development in early childhood is part of efforts of capability development of cognitive development in general such as auditory, visual, tactics, kinesthetic, arithmetic, geometry, and science, so that in the end of learning the child is able to develop their power of perception based on what is seen, heard and felt either naturally or scientifically so that children have a comprehensive understanding and can answer the problems that faced by them.
\end{abstract}

Keywords: Anak, Usia Dini, Cognitive development, dan PAUD

\section{A. Pendahuluan}

Setiap anak memiliki tingkat perkembangan yang berbeda dengan anak lainnya. Perbedaan tumbuh kembang mereka salah satunya dipengaruhi oleh lingkungan dan pendidikan di sekitar mereka. Sejak mereka lahir sampai dewasa, lingkungan dan pendidikan memegang peranan penting untuk menciptakan mereka menjadi apa, sehingga dalam hal ini orang dewasa tidak boleh salah dalam memberikan stimulasi pada masa pencapaian tumbuh kembang mereka. Usia 0-6 tahun merupakan masa peka bagi anak, dan para ahli menyebutnya dengan masa usia emas (the golden age), yakni masa terbaik atau kesempatan emas bagi anak untuk belajar.

Undang-undang RI nomor 20 tahun 2003 tentang sistem Pendidikan Nasional, pasal 28 ayat 3 juga menyatakan bahwa "Pendidikan anak usia dini adalah suatu upaya pembinaan yang ditujukan kepada anak sejak lahir sampai dengan usia enam tahun yang dilakukan melalui pemberian rangsangan pendidikan untuk membantu pertumbuhan dan perkembangan jasmani dan rohani agar anak memiliki kesiapan dalam memasuki pendidikan lebih lanjut."1

1 Undang-undang RI nomor 20 tahun 2003 tentang sistem Pendidikan Nasional, 
Pendidikan anak usia dini memegang peranan yang sangat penting bagi sejarah perkembangan anak selanjutnya, karena merupakan fondasi bagi kepribadian anak. Pendidikan anak usia dini sangat menentukan kesuksesan anak di masa depan. Bagaimana seseorang merespons berbagai permasalahan yang dihadapi dalam setiap langkah kehidupan sangat ditentukan oleh pengalaman dan pendidikan yang diperolehnya pada saat usia dini. Pendidikan anak usia dini yang positif akan mendorong seseorang untuk merespon berbagai permasalahan kehidupan secara positif; sebaliknya pengalaman negatif dapat mendorong seseorang melakukan sesuatu yang tidak sesuai dengan norma-norma kehidupan yang seharusnya. ${ }^{2}$

Pendidikan anak usia dini akan menjadi cikal bakal pembentukan karakter anak negeri sebagai titik awal pembentukan SDM berkualitas, yang memiliki wawasan, intelektual, kepribadian, tanggung jawab, inovatif, kreatif, proaktif, dan partisipatif hingga semangat mandiri. Hasil kajian menunjukkan bahwa anak-anak yang mengikuti pendidikan anak usia dini menjadi lebih mandiri, disiplin, dan mudah diarahkan untuk menyerap ilmu pengetahuan secara optimal.

Pentingnya Pendidikan anak usia dini juga dapat ditinjau dari perkembangan otak manusia, bahwa tahap perkembangan otak anak usia dini menempati posisi yang paling vital karena sebagian besar perkembangan otak dicapai pada masa usia dini. Lebih jelasnya, bayi lahir telah mencapai perkembangan otak $25 \%$ orang dewasa. Untuk menuju kesempurnaan perkembangan otak manusia 50\% dicapai hingga usia 4 tahun, 80\% hingga usia 8 tahun dan selebihnya diproses hingga anak usia 18 tahun. Dengan demikian, usia dini memegang peranan yang sangat penting karena perkembangan otak mengalami lompatan dan berjalan sedemikian pesat.

Keberadaan lembaga Pendidikan Anak Usia Dini (PAUD) diatur dalam Undang-undang Republik Indonesia nomor 20 tahun 2003 pada bab VI pasal 28 menyatakan bahwa: 1). Pendidikan anak usia dini diselenggarakan sebelum jenjang pendidikan dasar; 2). Pendidikan anak usia dini dapat diselenggarakan melalui jalur pendidikan formal, nonformal dan informal; 3). Pendidikan anak usia dini pada jalur formal berbentuk Taman Kanak-kanak (TK), Raudlatul Athfal (RA) atau bentuk lain sederajat; 4). Pendidikan anak usia dini pada jalur non formal

pasal 28 ayat 3 (Bandung: Citra Umbara, 2003), hlm.4.

2 E. Mulyasa, Manajemen PAUD, (Bandung: PT. Remaja rosdakarya., 2012), hlm.46.

$244 \mid$ JURNAL LISAN AL-HAL 
berbentuk Kelompok Bermain (KB), Taman Penitipan Anak (TPA) atau bentuk lain sederajat; dan 5). Pendidikan anak usia dini pada jalur informal berbentuk pendidikan keluarga atau pendidikan yang diselenggarakan oleh lingkungan. ${ }^{3}$

Pendidikan anak usia dini bertujuan membantu anak didik mengembangkan berbagai potensi baik psikis dan fisik yang meliputi moral dan nilai agama, sosial emosional, kemandirian, kognitif, bahasa, fisik/motorik, dan seni untuk siap memasuki sekolah dasar. ${ }^{4}$ Pengembangan berbagai potensi ini tidak akan berkembang melalui kematangan usia saja, melainkan harus ada stimulasi dan bimbingan dari para tenaga pendidik.

Salah satu aspek perkembangan anak tersebut adalah kognitif. Kognitif sering disinonimkan dengan intelektual karena prosesnya banyak berhubungan dengan berbagai konsep yang dimiliki anak dan berkenaan dengan kemampuan berpikirnya dalam memecahkan suatu masalah. Jika anak mendapat kesempatan untuk melakukan kegiatan yang banyak menstimulasi pikirannya, maka kecerdasan kognitifnya akan berkembang dengan maksimal. Hal tersebut penting, karena dalam proses kehidupannya, anak akan menghadapi berbagai persoalan yang harus dipecahkan.

Faktor kognitif mempunyai peranan penting bagi keberhasilan anak dalam belajar, karena sebagian aktivitas belajar selalu berhubungan dengan mengingat dan berpikir. Kedua aktivitas kognitif ini perlu dikembangkan. Tokoh psikologi kognitif Piaget, memandang anak sebagai partisipan aktif di dalam proses perkembangan. Piaget meyakini bahwa anak harus dipandang seperti seorang ilmuwan yang sedang mencari jawaban dalam upaya melakukan eksperimen terhadap dunia untuk melihat apa yang terjadi. 5

Perkembangan kognitif anak mengalami percepatan pada usia lima tahun pertama dalam kehidupan anak, kemudian melambat, dan akhirnya konstan pada akhir masa remaja. ${ }^{6}$ Oleh karena itu, diperlukan perhatian yang besar terhadap faktor-faktor yang memengaruhi perkembangan kognitif karena terdapat peran kematangan dan peran belajar dalam perkembangan tersebut yang menghasilkan pebedaan individual.

3 Undang-undang Republik Indonesia nomor 14 tahun 2005 tentang Guru dan Dosen, (Jakarta: CV Karya Gemilang, 2008), hlm.122.

4 Yuliani Nurani Sujiono, Konsep Pendidikan Anak Usia Dini,( Jakarta: PT INDEKS, 2009), hlm. 8.

5 E. Mulyasa, Manajemen PAUD, hlm.25.

${ }^{6}$ Ibid, hlm. 27. 
Perhatian tersebut diwujudkan dengan mengembangkan kognitif anak pada pendidikan pra sekolah bagi anak usia dini (PAUD), karena melalui kegiatan yang terstruktur, anak akan lebih terarah dalam perkembangannya.

Pengembangan kognitif anak perlu memerhatikan karakteristik anak dan prinsip-prinsip pendidikan anak usia dini. Pembelajaran harus menyenangkan bagi anak sehingga mereka tidak terbebani dalam proses belajarnya. Jika orientasi anak hanya ditekankan pada pencapaian prestasi akademik, maka mereka hanya dapat mencapai kemampuan sesuai harapan guru, yang boleh jadi dapat menimbulkan dampak negatif bagi perkembangan selanjutnya, misalnya belajar diterima sebagai tugas atau beban yang menyiksa, sehingga dapat menyebabkan kreativitas anak dan beberapa aspek perkembangan anak tersebut tidak berkembang optimal.

\section{A. Pembahasan}

\section{Pengertian Kognitif}

Kognitif adalah proses berpikir berupa kemampuan untuk menghubungkan, menilai, dan mempertimbangkan sesuatu atau dimaknai sebagai kemampuan untuk memecahkan masalah dan untuk mencipta karya. Sedangkan menurut Witherington sebagaimana yang dikutip oleh Ahmad Susanto mengatakan bahwa, "Kognitif adalah pikiran, melalui pikiran dapat digunakan dengan cepat dan tepat untuk mengatasi suatu situasi dan memecahkan masalah". ${ }^{7}$ Jika pikiran anak berkembang dengan cepat dan baik maka anak akan menjadi lebih cerdas. Anak akan berkembang lebih optimal dalam kehidupannya sejalan dengan tumbuh kembang anak yang bersangkutan. ${ }^{8}$

Kognitif adalah kemampuan individu untuk mengembangkan, menilai, dan mempertimbangkan suatu kejadian atau peristiwa. ${ }^{9}$ Ranah kognitif memiliki keterkaitan erat dengan intelegensi (kecerdasan) karena perkembangan kognitif merupakan perkembangan pikiran. Pikiran adalah bagian dari proses berpikir otak. Pikiran digunakan untuk mengenali, mengetahui, dan memahami yang mencirikan seseorang. Dengan dasar itu, aspek yang memengaruhi perkembangan daya pikir anak adalah: Kemampuan memecahkan masalah, kemampuan berpikir logis, kematangan intelegensi, kreatif, dan memiliki rasa ingin tahu yang tinggi. ${ }^{10}$

${ }^{7}$ Ahmad Susanto, Perkembangan Anak Usia Dini, (Jakarta, Kencana, 2011), hlm. 53.

${ }^{8}$ Ahmad Susanto, Perkembangan Anak Usia Dini, hlm. 52.

9 Ibid, hlm. 47.

10 Andang Ismail, Education Games, (Yogyakarta : Pro_U Media, 2009), hlm. 86.

$246 \mid$ JURNAL LISAN AL-HAL 
Jerome Brunner dalam bukunya Toward Theory of Instruction sebagaimana yang dikutip Slamet Suyanto menyatakan bahwa anak belajar dari konkret ke abstrak melalui tiga tahap:

a. Enective pada tahap ini anak berinteraksi dengan obyek berupa benda, orang dan kejadian, dari interaksi tersebut anak belajar nama dan merekam ciri benda dan kejadian

b. Iconic pada proses ini anak mulai belajar mengembangkan simbol dengan benda

c. Symbolic proses ini terjadi saat anak mengembangkan konsep dan mulai berpikir abstrak. ${ }^{11}$

Sedangkan Piaget mengidentifikasikan empat periode pertama dalam perkembangan kognitif, yakni:

a. Tahap sensorimotor (usia lahir sampai dua tahun) pada tahap ini anak berinteraksi dengan dunia sekitar melalui panca indra.

b. Tahap praoperasional (usia dua sampai tujuh tahun) pada tahap ini anak mulai menjelaskan dunia dengan kata-kata dan gambar. Tahap ini dibagi menjadi dua sub tahap: Pertama, periode prakonseptual (dua sampai empat tahun) yang terdiri dari munculnya berpikir simbolik dan berpikir egosentris diantaranya: 1). berpikir secara simbolik yaitu kemampuan berpikir tentang obyek dan peristiwa secara abstrak, ditambah dengan perkembangan kemampuan bahasa dan fantasi sehingga anak mempunyai dimensi baru dalam bermain; dan 2). berpikir secara egosentris yaitu anak melihat dunia dengan perspektifnya sendiri, menilai benar atau tidak berdasarkan sudut pandang sendiri sehingga anak belum meletakkan cara pandang dari sudut pandang orang lain. Kedua, periode intuitif (empat sampai tujuh tahun) yaitu kemampuan untuk menciptakan sesuatu tetapi tidak mengetahui alasan pasti mengapa melakukan demikian. Pada sub tahap ini, anak mulai menggunakan penalaran primitif dan ingin tahu jawaban atas semua banyak pertanyaan.

c. Tahap operasional konkret (usia tujuh sampai sebelas tahun), pada tahap ini anak dapat menalar secara logis mengenai kejadian konkret dan menggolongkan benda ke dalam kelompok yang berbeda.

d. Tahap operasional formal (usia sebelas sampai lima belas atau dewasa), pada tahap ini remaja melakukan penalaran dengan cara yang lebih abstrak, idealis dan logis. ${ }^{12}$

11 Slamet Suyanto, Dasar-dasar Pendidikan Anak Usia Dini, (Yoyakarta: Hikayat Publishing, 2005), cet. ke-1, hlm. 103.

12 Jhon W. Santrock, Perkembangan Anak, (Jakarta: Gelora Aksara Pratama, 2007),

\begin{tabular}{l|l} 
JURNAL LISAN AL-HAL & 247
\end{tabular} 


\section{Pengembangan Kognitif pada Anak Usia Dini}

Salah satu tujuan dari program pendidikan anak usia dini adalah membantu meletakkan dasar ke arah perkembangan sikap, pengetahuan, keterampilan dan daya cipta yang diperlukan oleh anak didik dalam menyesuaikan diri dengan lingkungannya dan untuk pertumbuhan serta perkembangan selanjutnya. Anak didik pada masa tersebut sedang dalam masa tumbuh kembang dan membutuhkan perhatian besar dari orang dewasa. Stimulasi dan bimbingan dari para tenaga pendidik saat anak melakukan kegiatan yang melibatkan aktivitas otak mereka akan sangat membantu optimalisasi berkembangnya berbagai aspek pada diri mereka.

Pengembangan kognitif pada pendidikan anak usia dini antara lain sebagai berikut: Pertama, pengetahuan umum dan Sains, meliputi: mengenal benda berdasarkan fungsi, menggunakan benda sebagai permainan simbolik, mengenal konsep sederhana dalam kehidupan sehari-hari (gerimis, hujan, gelap dsb), dan mengkreasikan sesuatu sesuai idenya.

Kedua, konsep bentuk, warna, ukuran, dan pola, meliputi: mengklasifikasikan benda berdasarkan warna, bentuk, dan ukuran, mengurutkan benda dari ukuran yang paling kecil ke besar atau sebaliknya.

Ketiga, Konsep bilangan, lambang bilangan dan huruf, meliputi: mengetahui konsep banyak dan sedikit, membilang banyak benda satu sampai sepuluh, mengenal lambang bilangan, mengenal lambang huruf, menyebutkan lambang bilangan, mencocokkan bilangan dengan lambang bilangan, dan mengenal berbagai macam lambang huruf vokal dan konsonan.

Guru memiliki peran besar dalam mengembangkan kognitif anak di pra sekolah. Peran guru sebagai stimulus akan menentukan ketercapaian tumbuh kembang anak secara optimal. Stimulasi guru diwujudkan dalam program kegiatan belajar yang diselenggarakan. Pelaksanaan pembelajaran di lembaga pendidikan anak usia dini perlu dipersiapkan dengan sebaik-baiknya, karena dengan perencanaan yang baik akan menghasilkan proses pembelajaran yang baik. Perencanaan yang dibuat menyesuaikan pada Program Tahunan dan Program Semester. Perencanaan meliputi penentuan metode dan teknik pembelajaran, pemilihan media, dan penilaian yang akan dilakukan. Perencanaan guru dalam pembelajaran yang akan dilakukan bertujuan untuk

jilid 1, hlm. 49.

$248 \mid$ JURNAL LISAN AL-HAL 
mengoptimalkan beberapa aspek perkembangan anak meliputi fisik/motorik, kognitif, moral, agama, bahasa, sosial emosional, dan seni.

Dalam proses pembelajaran, tekanan harus diletakkan pada pemikiran guru, oleh karenanya penting bagi guru untuk dapat mengerti cara berpikir anak, mengembangkan dan menghargai pengalaman anak, memahami bagaimana anak mengatasi suatu persoalan, menyediakan dan memberikan materi sesuai dengan taraf perkembangan kognitif agar lebih berhasil membantu anak berpikir dan membentuk pengetahuan, dan menggunakan berbagai metode belajar bervariasi yang dapat memungkinkan anak kreatif mengkonstruksi pengetahuan. ${ }^{13}$

Metode pembelajaran yang dapat diaplikasikan dalam pendidikan anak usia dini antara lain metode ceramah, metode tanya jawab, metode pembiasaan, metode keteladanan, metode bermain, metode bernyanyi, metode bercerita, metode wisata alam, metode pemecahan masalah, dan metode simulasi. ${ }^{14}$ Metode-metode tersebut perlu disesuaikan dengan karakteristik anak, kondisi kelas, dan materi yang akan diberikan. Pengembangan kognitif pada anak usia dini perlu melibatkan anak secara aktif, sehingga guru tidak menggunakan satu metode saja tetapi dapat mengkombinasikan beberapa metode dalam pembelajaran.

Guru perlu membuat perencanaan pembelajaran dengan matang. Guru perlu menyesuaikan dengan kondisi kelas (misalnya jumlah anak) yang berbeda-beda pada setiap kelas. Selanjutnya, Guru perlu mengecek dan mendiskusikan terlebih dahulu metode dan media yang akan digunakan pada hari sebelumnya, agar dapat memanfaatkannya dengan maksimal dan dapat menciptakan suasana belajar yang menyenangkan.

Perencanaan dan pelaksanaan pembelajaran pada pengembangan kognitif anak perlu memerhatikan tujuh prinsip pendidikan anak usia dini, karena sangat menentukan kualitas pembelajaran yang diselenggarakan, yakni:

a. Berorientasi pada kebutuhan anak. Kegiatan pembelajaran pada anak harus senantiasa berorientasi pada kebutuhan anak. Anak usia dini adalah anak yang sedang membutuhkan upaya-upaya pendidikan untuk mencapai optimalisasi semua aspek perkembangan. Guru perlu memberikan kesempatan seluas-luasnya pada anak untuk berkreasi

13 Yuliani Nurani Sujiono, Konsep Dasar Pendidikan Anak Usia Dini, (Jakarta: Indeks, 2009) hlm. 13

14 Muhammad Fadlillah, Desain Pembelajaran PAUD, (Jogjakarta: Ar Ruz Media, 2014), hlm.163. 
dan berimprovisasi sesuai dengan kegiatan belajar dan bermain yang dipilihnya.

b. Belajar melalui bermain. Bermain merupakan sarana belajar anak usia dini. Bermain merupakan aktivitas yang penting dilakukan anak sebab dengan bermain anak akan bertambah pengalaman dan pengetahuannya. Bermain dapat menstimulasi anak untuk terlibat aktif dalam pembelajaran, sehingga dapat mengoptimalkan tumbuh kembangnya. Masa kanak-kanak merupakan masa bermain, sehingga kegiatan pendidikan diberikan melalui bermain sambil belajar dan belajar seraya bermain. Dalam konteks ini, belajar dengan bermain memberi kesempatan kepada anak untuk memanipulasi, mengulangulang, menemukan sendiri, bereksplorasi, mempraktikkan dan mendapatkan bermacam-macam konsep. Di sinilah proses pembelajaran terjadi sehingga guru harus mengetahui arti bermain bagi anak. ${ }^{15}$ Dalam mendidik anak maka harus memasuki dunianya, dunia anak kecil identik dengan permainan oleh sebab itu, mendidik sambil bermain adalah cara paling mutakhir untuk mendidik anak. ${ }^{16}$

c. Lingkungan yang kondusif. Lingkungan harus diciptakan sedemikian rupa sehingga menarik dan menyenangkan dengan memerhatikan keamanan serta kenyamanan yang dapat mendukung kegiatan pembelajaran. Lingkungan belajar harus didesain dengan menarik sehinga menghadirkan rasa senang dan tenang bagi anak saat mereka sedang belajar. Rasa senang dan tenang akan menjadi motivasi bagi anak untuk betah belajar di lingkungan pra sekolah.

d. Menggunakan pembelajaran terpadu. Pembelajaran pada anak usia dini harus menggunakan konsep pembelajaran terpadu yang dilakukan melalui tema. Tema yang dibangun harus menarik, dapat membangkitkan minat anak dan bersifat kontekstual. Hal ini dimaksudkan agar anak mampu mengenal berbagai konsep secara mudah dan jelas sehingga pembelajaran menjadi mudah dan bermakna bagi anak.

e. Mengembangkan berbagai kecakapan hidup. Mengembangkan kecakapan hidup/ keterampilan hidup dapat dilakukan melalui proses pembiassaan. Hal ini dimaksudkan agar anak belajar untuk menolong diri sendiri, mandiri, bertanggung jawab, dan memiliki disiplin diri. hlm. 3 .

${ }^{15}$ Anggani Sudono, Alat Permainan dan Sumber Belajar TK, (Jakarta: Ditjen Dikti),

16 Mayke S. Tedjasaputra, Bermain Maianan dan Permainan, (Jakarta: PT Grasindo, 2007), cet. ke-4, hlm.20.

$250 \mid$ JURNAL LISAN AL-HAL 
f. Menggunakan berbagai media edukatif dan sumber belajar. Media dan sumber belajar dapat berasal dari lingkungan/ alam sekitar dan bahan-bahan yang sengaja disiapkan oleh pendidik agar pembelajaran dapat berkualitas dan menyenangkan bagi anak.

g. Dilaksanakan secara bertahap dan berulang-ulang. Pembelajaran bagi anak usia dini hendaknya dilakukan secara bertahap, dimulai dari konsep yang sederhana dan dekat dengan anak. Guru perlu menyajikan kegiatan-kegiatan yang berulang agar konsep dapat dikuasai anak dengan baik ${ }^{17}$.

Salah satu prinsip pendidikan anak usia dini diatas adalah belajar melalui bermain. Dunia anak adalah dunia bermain. Sehingga salah satu metode yang digunakan guru pada pengembangan kognitif anak adalah melalui kegiatan bermain. Kecenderungan manfaat bermain bagi perkembangan kognitif anak diantaranya menguasai berbagai konsep dasar, mengembangkan kreativitas, memberikan pengalaman untuk bereksplorasi dan memberi kepuasan kepada anak untuk menciptakan sesuatu. ${ }^{18}$

Bermain yang dilakukan oleh anak adakalanya bermain bersama teman atau bermain menggunakan alat permainan. Kegiatan bermain tersebut harus selalu dibawah pengawasan guru, sebagaimana aktivitas berkegiatan bebas yang terkadang dilakukan pada pengembangan kognitif anak pra sekolah. Bermain bebas atau berkegiatan bebas (tetapi tetap dalam pengawasan guru) yang dilakukan merupakan aplikasi teori kognitif Piaget dalam pembelajaran, yakni menjadikan ruang kelas menjadi ruang eksplorasi dan penemuan, sedangkan guru mengarahkan anak didik agar melakukan eksplorasi dan menemukan kesimpulan sendiri. Hal tersebut perlu dilakukan sebagai salah satu teknik pembelajaran agar anak bereksplorasi dengan lingkungannya, misalnya dengan bermain, bercerita, menggambar, memainkan APE dan sebagainya sehingga pada akhirnya mereka dapat berkreasi dan menemukan karyanya. Hal tersebut dapat mengoptimalkan kerja otak yang berhubungan erat dengan pengembangan kognitifnya.

Untuk mengetahui ketercapaian aspek perkembangan kognitif anak, penilaian perlu dilakukan setiap hari disesuaikan dengan tema dan kegiatan belajar, sebagaimana aplikasi teori Piaget dalam pembelajaran,

17 Jamal Ma'mur Asmani, Manajemen Strategis Pendidikan Anak Usia Dini, (Diva Press. Jogjakarta. 2009), hlm.72

${ }_{18}$ Ahmad Susanto, Perkembangan Anak Usia Dini, (Jakarta: Kencana Prenada Media Group, 2011), hlm. 130. 
yakni guru harus melakukan penilaian terus-menerus, karena makna yang disusun setiap anak didik tidak dapat diukur dengan tes standar. Penilaian dilakukan guru untuk menilai kemajuan dan hasil akhir. Dengan melakukan penilaian terus-menerus, maka guru akan mengetahui perkembangan anak didik dengan lebih jelas, sehingga ketika ditemukan masalah dari perkembangan anak, guru akan cepat mencari solusi dan memberikan tindakan yang tepat. Penilaian guru pada pengembangan kognitif anak dapat menggunakan berbagai teknik seperti observasi, unjuk kerja, penugasan, dan anekdot.

Dalam buku pedoman penilaian di Taman Kanak-kanak dan Raudhatul Athfal disebutkan bahwa penilaian merupakan proses pengumpulan dan pengolahan informasi untuk menentukan tingkat pencapaian perkembangan anak, pengambilan keputusan, pengakuan, atau ketetapan tentang kemampuan (kondisi) anak. ${ }^{19}$

Secara garis besar, prinsip umum penilaian dalam pembelajaran anak usia dini yaitu menyeluruh, berkesinambungan, objektif, autentik, edukatif, dan bermakna. ${ }^{20}$ Beberapa prinsip penilaian tersebut perlu diperhatikan agar dapat memaksimalkan fungsi penilaian dalam pengembangan kognitif anak. Fungsi penilaian adalah sebagai berikut:

a. Memberikan umpan balik kepada guru untuk memperbaiki rancangan kegiatan pelaksanaan program

b. Memberikan informasi kepada orang tua tentang ketercapaian pertumbuhan dan perkembangan anak agar dapat memberikan bimbingan dan dorongan yang sesuai untuk memperbaiki tumbuh kembang anak

c. Sebagai bahan pertimbangan guru untuk menempatkan anak dalam kegiatan pelaksanaan program yang dilakukan sesuai dengan minat dan kemampuan anak agar dapat mencapai kemampuan secara optimal

d. Sebagai bahan masukan bagi pihak lain yang memerlukan dan berkepentingan memberikan binaan selanjutnya demi mengembangkan semua potensi anak. ${ }^{21}$

Pengembangan aspek kognitif perlu diperhatikan sejak dini, karena tanpa adanya stimulasi yang tepat, aspek tersebut tidak akan berkembang dengan baik. Anak akan mampu melakukan penalaran, baik yang terjadi

${ }^{19}$ Suyadi, Implementasi dan Inovasi Kurikulum Paud 2013, (Bandung: Remaja Rosdakarya, 2014), hlm.112.

${ }^{20}$ Suyadi, Implementasi dan Inovasi Kurikulum Paud 2013, hlm. 114

${ }^{21}$ Anita Yus, Penilaian Perkembangan Belajar Anak Taman Kanak-kanak, (Jakarta: Kencana, 2012), hlm. 60

$252 \mid$ JURNAL LISAN AL-HAL 
secara alamiah (spontan) maupun melalui ilmiah (percobaan), dan anak mampu memecahkan persoalan hidup yang dihadapi sehingga pada akhirnya anak akan menjadi individu yang mampu menolong dirinya sendiri.

Tahapan-tahapan pengembangan kognitif pada anak usia dini dilakukan sebagai upaya pada pengembangan kemampuan auditory, visual, taktik, kinestetik, aritmetika, geometri, dan sains permulaan sebagai bagian dari pengembangan kognitif secara umum, sehingga pada akhirnya anak mampu mengembangkan daya persepsinya berdasarkan apa yang dilihat, didengar dan dirasakan sehingga anak memiliki pemahaman yang utuh dan komprehensif dan dapat menjawab permasalahan yang dihadapinya.

\section{Media dalam Pengembangan Kognitif Anak Usia Dini di Raudhatul Athfal}

Secara harfiah kata media adalah perantara atau pengantar. Association for Education and Communication Technology (AECT) mendefinisikan media yaitu segala bentuk yang dipergunakan untuk suatu proses penyaluran informasi sedangkan Nations Education Association (NEA) mendefinisikan media sebagai benda yang dapat dimanipulasi, dilihat, didengar, dibaca atau dibicarakan beserta instrumen yang dipergunakan dengan baik dalam kegiatan belajar mengajar yang dapat memengaruhi efektifitas program instruktional. ${ }^{22}$

Media merupakan sesuatu yang bersifat menyalurkan pesan dan dapat merangsang pikiran, perasaan dan kemauan anak didik sehingga dapat mendorong terjadinya proses belajar pada dirinya. Penggunaan media secara kreatif memungkinkan anak didik untuk belajar lebih baik dan dapat membantu guru dalam proses pembelajaran di kelas sehingga materi pembelajaran lebih dipahami oleh anak didik.

Dalam pembelajaran, media menjadi hal penting untuk digunakan karena dapat mempermudah penyampaian informasi oleh guru kepada siswa/anak. Media pembelajaran dapat memudahkan guru dalam pengembangan kognitif yang dilakukan karena keberadaan media membantu guru dalam pembelajaran. Anak-anak akan lebih memerhatikan guru, mengikuti bimbingan dan arahan dari guru, serta tetap antusias dalam pembelajaran. Media pembelajaran tersebut harus memiliki aspek kemenarikan, agar setiap anak yang terlibat dalam proses

22 Asnawir. M. Basyiruddin Usman, Media Pembelajaran, (Jakarta: PT. Intermasa, 2002), cet. ke-1, hlm. 11.

\begin{tabular}{l|l} 
JURNAL LISAN AL-HAL & 253
\end{tabular} 
pembelajaran merasa tertarik untuk memperhatikan dan bahkan menggunakan media tersebut.

Menurut Kemp dan Dayton sebagaimana yang dikutip Ahmad Fadlillah, manfaat media dalam pembelajaran antara lain sebagai berikut: a). Penyampaian materi pembelajaran dapat diseragamkan; b). Proses pembelajaran menjadi lebih menarik; c). Pembelajaran menjadi lebih interaktif; d). Kualitas belajar dapat ditingkatkan; e). Proses pembelajaran dapat dilakukan dimana saja dan kapan saja; f). Sikap positif siswa pada pembelajaran dapat ditingkatkan; g). Peran guru dapat berubah ke arah yang lebih positif dan produktif. ${ }^{23}$

Media dalam pembelajaran mempunyai nilai-nilai praktis sebagai berikut: a). Media dapat mengatasi keterbatasan pengalaman yang dimiliki anak; b). Media memungkinkan adanya interaksi langsung antara siswa dan lingkungan; c). Media menjadikan keseragaman pengamatan; d). Media dapat membangkitkan keinginan dan minat baru; e). Media dapat memberikan pengalaman yang integral dari suatu yang konkret sampai kepada yang abstrak; f). Media menanamkan konsep dasar yang benar, konkret, dan realitas; dan g). Media dapat membangkitkan motivasi dan merangsang anak belajar ${ }^{24}$

Media merupakan alat bantu untuk mencapai indikator aspek perkembangan yang maksimal. Media digunakan dalam pengembangan kognitif anak untuk menstimulasi keaktifan anak dalam pembelajaran dan memperjelas materi yang diberikan. Selain dapat melatih kepekaan berpikir, media digunakan sebagai alat bermain yang dapat menghilangkan kebosanan anak, alat untuk bereksperimen, dan menghasilkan kreasi baru. Media dalam pengembangan kognitif anak misalnya flash card, balok unit, balok berongga, balok berwarna, lego, puzzle, mainan angka, mainan huruf, buah-buahan, dan alat permainan lainnya yang bernilai edukatif.

Pengembangan kognitif anak usia dini antara lain melalui pengenalan pada konsep-konsep sederhana seperti besar dan kecil, banyak dan sedikit, warna, manfaaat benda, dan sebagainya melalui media pembelajaran. Penggunaan media ini diharapkan dapat melatih kemandirian dan keberanian anak, memahami konsep sederhana, mengenal manfaat benda, memecahkan masalah, dan membuat karya.

Antusias anak perlu diperhatikan saat guru menggunakan media/ alat permainan, sebagai evaluasi terhadap respon anak pada media

23 Muhammad Fadlillah, Desain Pembelajaran PAUD,hlm. 208.

${ }^{24}$ Ibid

254 JURNAL LISAN AL-HAL 
tersebut. Respon anak merupakan hal penting untuk diperhatikan, karena pembelajaran tidak hanya mementingkan ketercapaian target pembelajaran, tetapi juga adanya rasa senang dan nyaman.

Penggunaan media membutuhkan perencanaan yang baik sebelum mengimplementasikannya dalam proses pembelajaran . Penggunaan media akan sia-sia jika guru salah memanfaatkannya. Guru harus benarbenar cermat memilih media, agar nilai guna dari media yang digunakan tersebut dapat membantu anak dalam pengalaman belajarnya. Begitu juga sebaliknya, media sederhana akan memiliki nilai edukatif yang tinggi jika guru pintar memanfaatkannya dengan bimbingan yang tepat dalam proses pembelajaran.

Guru perlu menyadari sepenuhnya bahwa lingkungan sangat efektif sebagai sumber dan media belajar melalui bermain bagi anak usia dini. Secara kreatif guru dapat menggunakan media yang berasal dari lingkungan (bahan alam) dan bahan bekas/ bahan sisa. Guru harus mampu merencanakan, mempersiapkan, melaksanakan, mengevaluasi kegiatan, dan mengatur waktu dengan baik saat menggunakan media dalam mengembangkan kognitif anak. Usaha yang keras dan tepat dari seorang guru dapat memberikan hasil yang terbaik kepada anak sehingga dapat menentukan kualitas dalam kegiatan pembelajaran.

Dalam menggunakan media, stimulasi penting dilakukan guru misalnya dengan cara memberikan pertanyaan mudah pada anak dan memberikan contoh cara menggunakan media. Media pembelajaran tidak hanya digunakan untuk menjelaskan materi, tetapi juga media dapat digunakan anak secara langsung sebagai stimulasi bagi mereka untuk mengembangkan aspek kognitif. dalam penggunaan media tersebut, guru harus tetap memberikan stimulasi pada anak, misalnya bertanya tentang warna, jumlah, bentuk, dan fungsi, sehingga secara tidak langsung merangsang kerja otak anak untuk mencari jawaban dan penyelesaian masalah yang diberikan guru. beberapa pertanyaan ringan tersebut merupakan konsep dasar anak untuk mengembangkan kognitifnya.

Yusuf Hadi Miarso sebagaimana dikutip Ahmad Fadlillah menyebutkan pedoman-pedoman umum dalam menggunakan media pembelajaran sebagai berikut: 1). Penggunaan media harus didasarkan pada tujuan pembelajaran yang dicapai; 2). Penggunaan media harus mempertimbangkan kecocokan ciri media dengan karakteristik materi yang disajikan; 3). Penggunaan media harus disesuaikan dengan bentuk belajar yang dilaksanakan; 4). Penggunaan media harus disertai persiapan yang matang; 5). Anak perlu disiapkan sebelum media digunakan; dan 6). 
Penggunaan media harus dapat melibatkan anak secara aktif dalam pembelajaran $^{25}$

Peran media dalam komunikasi pada anak usia dini adalah konsep kekonkretan. Prinsip kekonkretan tersebut memerlukan media sebagai saluran penyampai pesan dari guru kepada anak usia dini. Harapannya, dengan adanya pesan melalui media konkret tersebut, anak usia dini mengalami perubahan-perubahan perilaku berupa kemampuankemampuan pengetahuan, sikap, dan keterampilan. ${ }^{26}$ Manfaat media yang begitu besar dalam proses pembelajaran memerlukan peran guru untuk dapat memanfaatkan media tersebut dengan baik, agar nilai guna dari media yang digunakan dapat berfungsi optimal.

\section{Problematika Pengembangan Kognitif Anak Usia Dini}

Salah satu hal yang menjadi kendala guru dalam pengembangan kognitif anak adalah daya konsentrasi anak yang bermacam-macam. Konsentrasi sebagian anak rendah karena salah satunya disebabkan usia yang belum siap belajar. Menurut Ahmad Susanto, Faktor yang dapat memengaruhi perkembangan kognitif antara lain adalah Faktor kematangan. Tiap organ (fisik maupun psikis) dapat dikatakan matang jika telah mencapai kesanggupan menjalankan fungsi masing-masing, kematangan berhubungan erat dengan usia kronologis (usia kalender).

Usia harus menjadi pertimbangan orang tua disaat akan memasukkan anaknya ke lembaga pendidikan, karena kematangan berkaitan dengan usia mereka. Anak yang memiliki daya konsentrasi rendah, harus selalu menerima bimbingan, latihan, dan arahan agar terbiasa dengan kegiatan menyimak dan melaksanakan tugas yang diberikan guru, karena kegiatan menyimak juga berhubungan dengan daya konsentrasi anak.

Anak adalah pribadi yang unik, mereka memiliki karakter dan kemampuan yang berbeda satu dengan lainnya. Dalam pembelajaran yang dilakukan, guru harus pandai melihat semua perbedaan tersebut dan memperlakukan anak sesuai kebutuhan mereka. Guru harus menginterpretasikan apa yang dikatakan anak didik dan merespon dengan memberikan wacana sesuai dengan tingkat pemikiran anak didik sehingga anak dapat membangun sendiri pengetahuaannya dan belajar untuk

25 Muhammad Fadlillah, Desain Pembelajaran PAUD, hlm. 210.

${ }^{26}$ Luluk Asmaawati, Perencanaan Pembelajaran PAUD, (Bandung: Remaja Rosdakarya, 2014), hlm.36.

256 JURNAL LISAN AL-HAL 
menyelesaikan masalahnya sendiri. Faktor yang dapat memengaruhi perkembangan kognitif sebagai berikut :

a. Faktor hereditas atau keturunan. Teori hereditas atau nativisme dipelopori oleh seorang ahli filsafat Schopenhauer berpendapat "Manusia lahir sudah membawa potensi tertentu yang tidak dapat dipengaruhi oleh lingkungan". Dikatakan pula bahwa taraf intelegensi sudah ditentukan sejak dilahirkan sadangkan para ahli psikologi Lehrin, Lindzey dan Spuhier berpendapat bahwa taraf intelegensi 7580\% merupakan warisan atau faktor keturunan.

b. Faktor lingkungan. Teori lingkungan atau empirisme dipelopori oleh John Locke yang berpendapat "Manusia dilahirkan dalam keadaan suci seperti kertas putih yang masih bersih belum ada tulisan atau noda sedikitpun". Teori ini dikenal dengan sebutan tabularasa, berdasarkan pendapat Locke bahwa taraf intelegensi sangatlah ditentukan oleh pengalaman dan pengetahuan yang diperoleh dari lingkungan hidupnya

c. Faktor kematangan tiap organ (fisik maupun psikis) dapat dikatakan matang jika telah mencapai kesanggupan menjalankan fungsi masingmasing, kematangan berhubungan erat dengan usia kronologis (usia kalender)

d. Faktor pembentukan, yakni segala keadaan di luar diri seseorang yang memengaruhi perkembangan intelegensi. Pembentukan dapat dibedakan menjadi pembentukan sengaja (pengaruh alam sekitar), sehingga manusia berbuat intelegen karena untuk mempertahankan hidup ataupun dalam bentuk penyesuaian diri.

e. Faktor minat dan bakat minat mengarahkan perbuatan kepada suatu tujuan dan merupakan dorongan untuk berbuat lebih giat dan lebih baik lagi. Bakat adalah kemampuan bawaan sebagai potensi yang masih perlu dikembangkan dan dilatih agar dapat terwujud. Bakat seseorang akan memengaruhi tingkat kecerdasan, artinya seseorang yang memiliki bakat tertentu maka akan semakin mudah dan cepat mempelajarinya

f. Faktor kebebasan, yaitu keleluasaan manusia untuk berpikir divergen (menyebar) bahwa manusia dapat memilih metode tertentu dalam memecahkan masalah juga bebas dalam memilih masalah sesuai kebutuhannya. ${ }^{27}$

Dr. Rose Mini A. P., M. Psi. selaku psikolog anak mengatakan "Intellegensi Quoentient (kecerdasan kognitif) seorang anak dipengaruhi

${ }^{27}$ Ahmad Susanto, Perkembangan Anak Usia Dini. hlm. 59. 
oleh dua faktor yaitu nature (genetik) dan nurture (stimulasi)". Pengaruh stimulasi sejajar dengan faktor genetik umum berdasarkan pengamatan, faktor stimulasi paling banyak berperan dalam menentukan masa depan anak, ${ }^{28}$ sehingga perkembangan berpikir sangat berkaitan dengan struktur otak yang dipengaruhi oleh stimulasi.

Pembelajaran anak harus berjalan secara alamiah. Anak tidak boleh didesak dan ditekan untuk berprestasi terlalu banyak di awal perkembangan sebelum siap. Hal tersebut juga harus dipertimbangkan oleh guru dalam proses pembelajaran yang dilakukan. Guru harus dapat menciptakan pembelajaran menjadi enjoyfull learning. Biarkan anak menikmati dunianya, sampai dia ada pada fase siap untuk benar-benar belajar.

Guru yang tidak pernah mengembangkan pengetahuan, keahlian dan eksplorasi mengenai hal baru dapat dipastikan akan mengajar secara monoton. Di sinilah profesionalitas guru mendapat tantangan, tantangan paling utama adalah membuat inovasi yang tepat dalam kegiatan belajarmengajar sehingga lebih hidup dan bermakna, dengan kata lain guru mengajar dengan menggunakan metode konvensional akan membosankan anak didik. ${ }^{29}$

Paradigma kegiatan guru dan anak didik di kelas pada umumnya masih bersifat komunikasi satu arah, guru mengajar dan anak didik belajar, guru pemain dan anak didik penonton. Cara konvensioanal seperti ini akan membentuk generasi anak yang hanya bisa menerima sesuatu yang sudah jadi. Padahal untuk membekali generasi yang akan datang haruslah dengan membiasakan anak beraktivitas agar mereka bisa mandiri dan bermanfaat bagi lingkungannya. Hal ini hanya akan terbentuk melalui kegiatan yang bisa dan membiasakan diri mengembangkan potensi diri berupa kognitif, afektif dan psikomotir sehingga memiliki berbagai kompetensi sebagai bekal kehidupannya. ${ }^{30}$

Pandangan teori Piaget tentang guru dalam hakikat pembelajaran pendidikan anak didik adalah: 1). Gunakan pendekatan konstruktivis artinya anak akan belajar dengan lebih baik jika anak aktif dan mencari solusi sendiri bukan dengan diajari menyalin apa yang dikatakan atau dilakukan guru; 2) Fasilitasi anak didik untuk belajar, guru yang efektif harus merancang situasi membuat anak didik dengan bertindak (learning

${ }^{28}$ As'adi Muhammad, Panduan Praktis Stimulasi Otak Anak, (Jogjakarta: Diva Press, 2010), cet. ke-1, hlm. 30 .

${ }^{29}$ Masykur Arif Rahman, Kesalahan-kesalahan Fatal Paling Sering Dilakukan Guru dalam Kegiatan Belajar-Mengajar, (Jogjakarta: Diva Press, 2-11), cet. ke-1, hlm.55

${ }_{30}$ Ajeng Yusriana, Kiat-kiat menjadi Guru Paud yang Disukai Anak-anak, hlm.81.

$258 \mid$ JURNAL LISAN AL-HAL 
by doing) situasi seperti ini akan meningkatkan pemikiran dan penemuan anak didik; 3). Pertimbangkan pengetahuan dan tingkat pemikiran anak, artinya guru harus menginterpretasikan apa yang dikatakan anak didik dan merespon dengan memberikan wacana sesuai dengan tingkat pemikiran anak didik; 4). Gunakan penilaian terus-menerus, makna yang disusun setiap anak didik tidak dapat diukur dengan tes standar; 5). Tingkat kemampuan intelektual anak didik artinya pembelajaran anak harus berjalan secara alamiah. Anak tidak boleh didesak dan ditekan untuk berprestasi terlalu banyak di awal perkembangan sebelum siap; dan 6). Jadikan ruang kelas menjadi ruang eksplorasi dan penemuan, guru menekankan agar anak didik melakukan eksplorasi dan menemukan kesimpulan sendiri. ${ }^{31}$

Tokoh pendidikan Ki Hajar Dewantara mengemukakan "Guru hendaknya menjadi pribadi bermutu dalam kepribadian dan kerohanian kemudian menyediakan diri menjadi pahlawan dan menyiapkan anak didik menjadi pembela nusa dan bangsa",32 oleh karena itu tugas pendidik baik orang tua ataupun guru mengarahkan kemana anak akan dibawa dengan konsep yang sudah disiapkan dan mengkomunikasikan hasil belajar anak pada orang tua sebagai tindak lanjut dari pembelajaran dan evaluasi yang dilaksanakan. Beberapa hal diatas harus diperhatikan oleh guru dalam proses pembelajaran yang dilakukan agar dapat mencapai indikator pengembangan kognitif anak dengan optimal.

\section{Urgensi Pengembangan Kognitif Anak Usia Dini}

J.S Renzulli menggambarkan ciri kemampuan kognitif (untuk anak berbakat kognitif) antara lain mudah menangkap pelajaran, ingatan baik, perbendaharaan kata luas, penalaran tajam (berpikir logis, kritis, memahami hubungan sebab akibat), daya konsentrasi baik, menguasai bahan tentang macam-macam topik, senang dan sering membaca, ungkapan diri lancar dan jelas. ${ }^{33}$

Tujuan pengembangan kognitif diarahkan pada pengembangan kemampuan auditory, visual, taktik, kinestetik, aritmatika, geometri dan sains permulaan. Uraian masing-masing bidang pengembangan ini sebagai berikut:

Pertama, pengembangan auditory, berhubungan dengan bunyi atau

${ }^{31}$ Dianah Mutiah, Psikologi Bermain Anak Usia Dini,(Jakarta: Kencana, 2010) hlm. 69.

${ }^{32}$ Yuliani Nurani Sujiono, Konsep Dasar Pendidikan Anak Usia Dini, hlm. 125.

${ }^{33}$ Ahmad Susanto, Perkembangan Anak Usia Dini, hlm. 54. 
indera pendengaran anak seperti a) mengetahui nama benda yang dibunyikan b) mendengarkan nyanyian atau syair dengan baik c) mengikuti perintah lisan sederhana d) mendengarkan cerita dengan baik e) mengungkapkan kembali cerita sederhana f) menebak lagu atau apresiasi musik g) mengikuti ritmis dengan bertepuk tangan $h$ ) menyebutkan nama-nama hari dan bulan

Kedua, pengembangan visual, berhubungan dengan penglihatan, pengamatan, perhatian, tanggapan dan persepsi anak terhadap lingkungan sekitarnya seperti a) mengenali benda-benda sehari-hari, b) membandingkan benda dari sederhana menuju lebih kompleks, c) mengetahui ukuran, bentuk dan warna benda, d) mengetahui adanya benda yang hilang apabila ditunjukkan sebuah yang belum sempurna atau janggal, e) mengenali huruf dan angka f) menyusun potongan teka-teki mulai dari sederhana sampai lebih rumit g) mengenali namanya sendiri bila tertulis.

Ketiga, pengembangan taktik, berhubungan dengan pengembangan tekstur (indera peraba) seperti a) mengembangkan akan indera sentuhan b) mengembangkan kesadaran akan berbagai tekstur c) mengembangkan kosakata untuk menggambarkan berbagai tekstur meliputi tebal-tipis, halus-kasar, panas-dingin dan tekstur kontras lainnya.

Keempat, pengembangan kinestetik, berhubungan dengan kelancaran gerak tangan atau motorik halus yang memengaruhi perkembangan kognitif seperti a) finger painting dengan tepung kanji b) menjiplak huruf geometri, c) melukis dengan cat air d) mewarnai dengan sederhana e) mampu menulis f) merobek kertas koran g) menciptakan bentuk dengan balok h) mewarnai gambar i) membuat gambar sendiri dengan berbagai media j) menjiplak bentuk lingkaran, dsb. k) memegang dan mengusai sebatang pensil l) mampu menggunakan gunting dengan baik

Kelima, pengembangan aritmetika, diarahkan untuk penguasaan berhitung konsep berhitung permulaan seperti a) mengenali atau membilang angka b) menyebut urutan bilangan c) menghitung benda d) menggunakan konsep waktu misalnya hari ini e) menyatakan waktu dengan jam f) menghubungkan konsep bilangan dengan lambang bilangan

Keenam, pengembangan geometri, berhubungan dengan pengembangan konsep bentuk dan ukuran seperti a) memilih dan mencocokkan benda menurut warna, bentuk dan ukuran b) mengenal ukuran panjang, berat dan isi c) membandingkan benda menurut ukuran besar, kecil, panjang, lebar, tinggi dan rendah d) mengukur benda secara sederhana e) mengerti dan menggunakan bahasa ukuran seperti besar- 
kecil, tinggi-rendah dan panjang-pendek ${ }^{34}$

Ketujuh, pengembangan sains permulaan, berhubungan dengan berbagai percobaan atau demonstrasi sebagai suatu pendekatan secara saintifik atau logis tetapi tetap dengan mempertimbangkan tahapan berpikir anak seperti a) mengeksplorasi berbagai benda yang ada disekitar b) mengadakan berbagai percobaan sederhana c) mengomunikasikan apa yang telah diamati dan diteliti. Contoh kegiatan yang dapat dikembangkan melalui permainan seperti proses merebus atau membakar jagung, , mengenal asal mula sesuatu, mencampur warna, dan mengenal sebab akibat ${ }^{35}$

Perkembangan kognitif adalah dari pikiran. Pikiran anak-anak sudah dapat bekerja aktif semenjak anak dilahirkan. Hari demi hari pemikiran anak berkembang sejalan dengan pertumbuhannya. Jika anak pikirannya berkembang cepat dan baik, maka anak akan berkembang lebih optimal dalam kehidupannya, sehingga juga akan beraktivitas dengan optimal. Dalam hal ini stimulasi yang baik akan membantu anak untuk dapat mengembangkan kognitifnya dengan baik.

Pentingnya guru mengembangkan kognitif pada anak menurut Piaget sebagaimana yang dikutip Ahmad Susanto adalah: a). Anak mampu mengembangkan daya persepsinya berdasarkan apa yang dilihat, didengar dan dirasakan sehingga anak memiliki pemahaman yang utuh dan komprehensif; b). Anak mampu melatih ingatan terhadap semua peristiwa dan kejadian yang pernah dialami; c). Anak mampu mengembangkan pemikiran dalam rangka menghubungkan satu peristiwa lain; d). Anak mampu memahami simbol yang tersebar di dunia sekitar; e). Anak mampu melakukan penalaran, baik yang terjadi secara alamiah (spontan) maupun melalui ilmiah (percobaan); dan f). Anak mampu memecahkan persoalan hidup yang dihadapi sehingga pada akhirnya anak akan menjadi individu yang mampu menolong dirinya sendiri. ${ }^{36}$

Gambaran yang diberikan Williams tentang ciri-ciri perilaku kognitif sebagaimana yang dikutip Ahmad Susanto adalah: a). Berpikir lancar, yaitu menghasilkan banyak gagassan atau jawaban yang relevan dan arus pemikiran lancar; b). Berpikir luwes, yaitu menghasilkan gagasan-gagasan yang beragam, mampu mengubah cara atau pendekatan dan arah pemikiran yang berbeda-beda; c). Berpikir orisinal, yaitu memberikan jawaban yang tidak lazim atau lain dari yang lain yang jarang

\footnotetext{
34 ibid.. 63.

35 Ibid

${ }^{36}$ Ahmad Susanto, Perkembangan Anak Usia Dini, hlm. 48.
} 
diberikan kebanyakan orang lain; dan d). Berpikir terperinci, yaitu mengembangkan, memperkaya suatu gagasan, memerinci detail-detail, dan memperluas gagasan. ${ }^{37}$

Dengan demikian, maka jelaslah betapa pentingnya mengembangkan kognitif anak pada usia dini, pada usia emas mereka. Melalui stimulasi yang baik, maka aspek kognitif anak akan berkembang optimal.

\section{B. Simpulan}

Tahapan Pengembangan kognitif dilakukan dalam rangka mengaktualisasikan seluruh potensi yang tersembunyi (the hidden potency) dalam diri masing-masing anak sehingga akan terwujud dalam bentuk perilaku nyata yang dapat diamati (the actual potency).

Anak usia dini ada pada masa meniru. Dalam proses modelling tersebut, diawali dengan perhatian (attention), penyimpanan (retention), dan fase memproduksi (production). Setelah tahap ini anak dapat termotivasi kembali untuk mengulanginya, sehingga guru sebagai stimulus harus menjadi contoh yang baik bagi anak.

Mengingat kembali suasana pendidikan yang diharapkan Ki Hadjar Dewantara yakni prinsip asah, asih, dan asuh, maka dalam pengembangan kognitif anak usia dini guru jangan terfokus untuk mengasah saja (ketercapaian target belajar), tetapi tetap mengasuh dengan penuh kasih pada anak, yakni dengan menghadirkan rasa senang, nyaman, dan tenang melalui kasih sayang dan perhatian guru.

\section{DAFTAR PUSTAKA}

Ahmad Susanto, Perkembangan Anak Usia Dini, Jakarta, Kencana, 2011. Andang Ismail, Education Games, Yogyakarta : Pro_U Media, 2009.. Anggani Sudono, Alat Permainan dan Sumber Belajar TK, Jakarta: Ditjen Dikti

Anita Yus, Penilaian Perkembangan Belajar Anak Taman Kanak-kanak, Jakarta: Kencana, 2012

Asnawir. M. Basyiruddin Usman, Media Pembelajaran, Jakarta: PT. Intermasa, cet. ke-1, 2002,

As'adi Muhammad, Panduan Praktis Stimulasi Otak Anak, Jogjakarta: Diva Press, cet. ke-1, 2010,

Dianah Mutiah, Psikologi Bermain Anak Usia Dini, Jakarta: Kencana, 2010

37 Ibid, hlm. 56.

$262 \mid$ JURNAL LISAN AL-HAL 
E. Mulyasa, Manajemen PAUD, Bandung: PT. Remaja Rosdakarya., 2012 Jamal Ma'mur Asmani, Manajemen Strategis Pendidikan Anak Usia Dini, Diva Press. Jogjakarta. 2009

Jhon W. Santrock, Perkembangan Anak, Jakarta: Gelora Aksara Pratama, 2007), jilid 1.

Luluk Asmaawati, Perencanaan Pembelajaran PAUD, Bandung: Remaja rosdakarya, 2014

Masykur Arif Rahman, Kesalahan-kesalahan Fatal Paling Sering Dilakukan Guru dalam Kegiatan Belajar-Mengajar, (Jogjakarta: Diva Press, 211), cet. ke-1

Mayke S. Tedjasaputra, Bermain Maianan dan Permainan, Jakarta: PT Grasindo, , cet. ke-4, 2007.

Muhammad Fadlillah, Desain Pembelajaran PAUD, Jogjakarta: Ar Ruz Media, 2014.

Slamet Suyanto, Dasar-dasar Pendidikan Anak Usia Dini, Yoyakarta: Hikayat Publishing, cet. ke-1, 2005.

Suyadi, Implementasi dan Inovasi Kurikulum Paud 2013, Bandung: Remaja Rosdakarya, 2014.

Undang-undang RI nomor 20 tahun 2003 tentang sistem Pendidikan Nasional, pasal 28 ayat 3, Bandung: Citra Umbara, 2003.

Undang-undang Republik Indonesia nomor 14 tahun 2005 tentang Guru dan Dosen, Jakarta: CV Karya Gemilang, 2008.

Yuliani Nurani Sujiono, Konsep Dasar Pendidikan Anak Usia Dini, Jakarta: Indeks, 2009. 
"Kognitif Development"

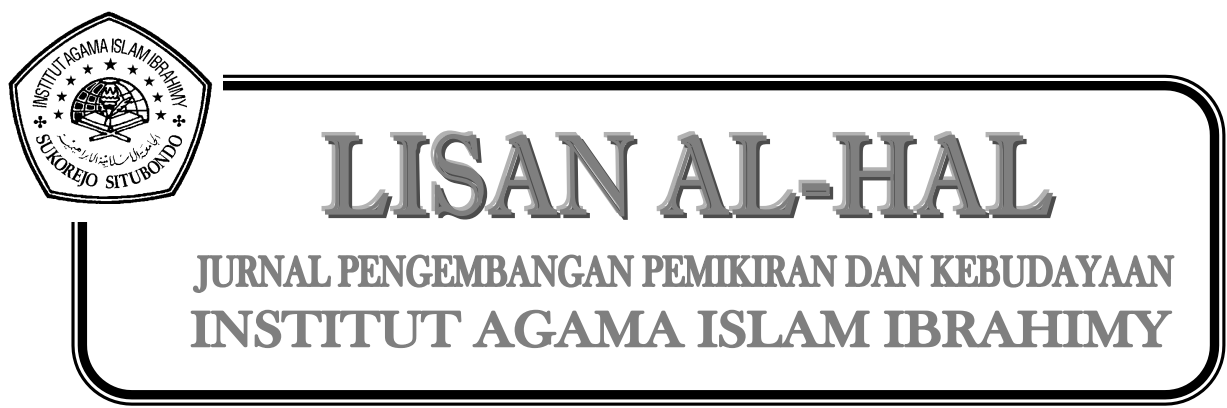

264 JURNAL LISAN AL-HAL 